\title{
KANDUNGAN MERKURI PADA TUMBUHAN PAKU (Diplazium accedens Blume) DI DAERAH TAMBANG EMAS TATELU-TALAWAAN, KABUPATEN MINAHASA UTARA
}

\author{
Altini O.Kosegeran ${ }^{1)}$, Sendy Rondonuwu' ${ }^{1)}$, Herny Simbala1), Marhaenus Rumondor ${ }^{1)}$ \\ ${ }^{1)}$ Program Studi Biologi FMIPA Universitas Sam Ratulangi Manado \\ e-mail : altinisindykosegeran@yahoo.com; rondonuwu64@yahoo.com; hsimbala@yahoo.co.id; \\ marhaenusrumondor66@yahoo.com
}

\begin{abstract}
ABSTRAK
Tumbuhan paku Diplazium accedens Blume merupakan tumbuhan yang termasuk suku polypodiales yang tumbuh di hutan, di daerah pegunungan, rawa, dan di sekitar sungai. Daun paku ini sering dikomsumsi masyarakat sebagai sayur-sayuran. Penelitian ini bertujuan untuk mengetahui kandungan merkuri pada tumbuhan paku di daerah tambang emas Tatelu-Talawaan. Lokasi penelitian terletak di daerah Tambang Emas Talawaan-Tatelu, Kabupataen Minahasa Utara. Metode yang digunakan adalah mencakup analisis sampel tumbuhan paku dan analisis sampel tanah dengan menggunakan Alat Direct Mercury Analyzer. Tumbuhan paku dan tanah yang di ambil di 3 lokasi sebanyak 9 sampel tumbuhan paku dan 3 sampel tanah. Dari 9 sampel tumbuhan paku tidak ada yang mengandung merkuri, sedangkan tanah dari 3 lokasi pada bagian yang $\mathrm{C}$ yang mengandung merkuri sebesar $0,6 \mathrm{ppm}$.
\end{abstract}

Kata kunci: Tanaman paku, merkuri, analisis tanah

\section{MERCURY CONTENT IN FERNS (Diplazium accedens Blume) IN THE GOLD MINE TATELU-TALAWAAN, NORTH MINAHASA DISTRICT}

\begin{abstract}
The fern Diplazium accedens Blume is a plant species belongs to Polypodiales family that grows in the forest, mountains, swamp, and near the river. This plant consumes as vegetable. This research aimed to measure the level of mercury in the fern grows near the Tatelu-Talawaan gold mining. The location for this research is the area of gold mining of Tatelu-Talawaan, North Minahasa. The methods used were plant analysis and soil analysis using Direct Mercury Analyzer. The plant and soil taken from three locations are consist of nine samples of plants and three samples of soil. None of the nine plant samples contained mercury and the soil from 3 locations contained 0.6 ppm of mercury.
\end{abstract}

Keywords:The fern, mercury, soil analysis

\section{PENDAHULUAN}

Tumbuhan paku (Diplazium accendens Blume) merupakan tumbuhan termasuk suku Polypodiales yang tumbuh di hutan, di daerahdaerah pegunungan, rawa, dan di sekitar kali (sungai) yaitu pada daerah teduh dan lembab. Pucuk paku ini sering dikonsumsi masyarakat sebagai sayur-sayuran.Sifat dasar zat merkuri, tidak dapat larut dalam air namun terus menumpuk di dalam tubuh manusia. Apabila dalam periode tertentu, seseorang secara terusmenerus terkontaminasi merkuri melalui makanan, minuman, dan melalui udara, maka akan menderita berbagai jenis penyakit yang sulit disembuhkan, diantaranya penyakit tremor. Melihat bahaya dari pencemaran merkuri terhadap lingkungan dan kesehatan manusia yang begitu besar, maka perlu dilakukan penelitian terhadap kandungan merkuri pada tumbuhan paku (Kinho, 2011).

Jenis tumbuhan paku ini memiliki rimpang yang tegak dan kokoh. Tangkai daun pada pangkalnya bersisik banyak dengan panjang $0,7 \mathrm{~mm}$, berwarna coklat. Helaian daun menyirip dengan anak-anak daun yang 
tidak bertangkai,panjang sampai $78 \mathrm{~cm}$, lebar sampai $18 \mathrm{~cm}$, tepi daun berlobus, bergigi, pada ujung anak-anak daun tidak memisah sehingga merupakan ujung yang bergigi. Tekstur daun tipis, kaku dengan warna hijau gelap.Pada permukaan bahwa tiap anak daun yang tersusun disepanjang urat-urat daun. Daun mudahnya dapat digunakan sebagai bahan makanan untuk dibuat sebagai sayur (Sastrapradja, et. al, 2002).

Penelitian ini bertujuan mengetahui kandungan merkuri (air raksa) pada tumbuhan paku (Diplazium accendens Blume) yang sering dikonsumsi oleh masyarakat di daerah pertambangan emas di Desa Talawaan-Tatelu, Kabupaten Minahasa Utara.

\section{METODE PENELITIAN}

Bahan yang digunakan pada penelitian ini yaitu tumbuhan pakis, tanah, es batu, larutan induk $\mathrm{Hg} 1000 \mathrm{mg} / \mathrm{L}, \mathrm{HNO}_{3}$ pekat, aquades. Alat yang digunakan adalah Direct Mercury Analyzer (DMA-80), soil tester, PH, timbangan analitik, kantung plastik, kertas label, spidol, pisau, labu ukur, pipet $1 \mathrm{ml}$, kamera.

\section{Teknik pengambilan sampel.}

Sampel tumbuhan paku dan tanah diambil dari ke-3 lokasi yang telah ditentukan.Titik I di Desa Talawaan (dekat pemukiman penduduk), titik II di Desa Tatelu (dekat sungai) dan titik III di Desa Tatelu Rondor (dekat tromol). Pada saat yang sama pula dilakukan pengukuranpH tanah.

Sampel tumbuhan pakuyang diambil yaitu 3 helaian daun muda pada setiap titik sampel dari tumbuhan yang sama untuk 3 (tiga) ulangan dan juga diambil 1 (satu) sampel tanah pada kedalaman 10-20 cm. Ke-3 helaian daun muda merupakan daun yang sering diambil dan dibuat sayuran serta dikonsumsi masyarakat Manado. Sampel yang telah diambil dimasukkan ke dalam wadah plastik yang sebelumnya telah dicuci dengan $\mathrm{HNO}_{3}$ dan diberi label sesuai lokasi pengambilan sampel. Selanjutnya sampel dimasukkan ke dalam kotak yang telah diberi es agar sampel tetap segar, dan langsung dibawa ke Laboratorium Baristan Manado.

Analisis sampel tumbuhan paku dilakukan di Laboratorium Balai Industri (BARISTAN) Manado dengan menggunakan alat Direct Mercury Analyzer (DMA-80).

\section{Analisis sampel tumbuhan paku}

1. Sampel tumbuhan paku dihaluskan dan dibuat homogen dengan cara dipotong-potong menjadi bagianbagian kecil lalu dimasukan ke dalam wadah dan diberi label.

2. Menimbang sampel sebanyak $\pm 0,5$ gram, dan menambahkan $1 \mathrm{ml} \mathrm{H}_{2} \mathrm{O}$ selanjutnya menambahkan $2 \mathrm{ml}$ $\mathrm{HNO}_{3}$ dan $\mathrm{HCL}$ sebanyak 5 tetes, serta menambahkan $5 \mathrm{ml} \quad \mathrm{H}_{2} \mathrm{SO}_{4}$ sebanyak 5 tetes.

3. Kemudian sampel dipanaskan pada suhu $\pm 200^{\circ}$ c selama 30 menit, dan selanjutkan didinginkan hingga temperatur ruang yaitu $27^{\circ} \mathrm{C}$.

4. Sampel dipindahkan ke labu ukur 200 $\mathrm{ml}$ dan dibilas, serta ditambahkan aquades bebas merkuri sampai batas tanda garis.

5. Sebelum diukur dengan alat AASMVU, sampel ditambahkan $5 \mathrm{ml}$ $\mathrm{N}_{\mathrm{a}} \mathrm{BH}_{4} 10 \%$.

\section{Analisis sampel tanah}

1. Menimbang tanah sebanyak 2 gr dan menambahkan 5 tetes $\mathrm{HNO}_{3}$ pekat sambil diaduk.

2. Selanjutnya menambahkan $10 \mathrm{ml}$ HCL sebanyak 5 tetes, dan memanaskan sampel tanah tersebut dalam penangan air sampai kering.

3. Kemudian ditambahkan air panas sebanyak $100 \mathrm{ml}$ dan disaring.

\section{Analisis data}

Data yang diperoleh disajikan dalam bentuk tabel. Data ini berupa data kandungan merkuri pada sampel tumbuhan paku dan tanah yang diambil pada 3 titik lokasi dengan 3 ulangan di pertambangan emas rakyat di Desa Talawaan-Tatelu, Kabupaten Minahasa Utara.

\section{HASIL DAN PEMBAHASAN}

Tumbuhan paku yang dianalisis berasal dari ke-3 lokasi yang terdapat di sekitar pertambangan emas rakyat di Desa Talawaan dan Desa Tatelu Kabupaten Minahasa Utara yaitu: (1) Lokasi 1 berjarak 500 meter dari lokasi tromol; (2) Lokasi ke-2 berjarak 250 meter dari lokasi tromol; dan (3)Lokasi 25 meter dari tromol. Sampel tumbuhan paku dan 
tanah langsung dibawa ke Balai Riset dan Standardisasi Industri Manado (BARISTAN), ntuk mengetahui kandungan merkuri yang terdapat dalam tumbuhan dan tanah tersebut.

Tabel 1. Kandungan Merkuri Pada Tumbuhan Paku

\begin{tabular}{|c|c|c|c|c|}
\hline No & Sampel & $\begin{array}{c}\text { Kadar } \\
\mathrm{Hg} \\
(\mathrm{ppm})\end{array}$ & $\begin{array}{c}\mathrm{pH} \\
\text { Tanah }\end{array}$ & $\begin{array}{c}\text { Standar } \\
\mathrm{Hg} \\
\text { Tumbuhan } \\
\text { (ppm) }\end{array}$ \\
\hline 1 & A1 & 0.00 & 6.5 & $0,001-0,03$ \\
\hline 2 & A2 & 0.00 & 6.8 & $0,001-0,03$ \\
\hline 3 & A3 & 0.00 & 7.0 & $0,001-0,03$ \\
\hline 4 & B1 & 0.00 & 6.6 & $0,001-0,03$ \\
\hline 5 & B2 & 0.00 & 6.8 & $0,001-0,03$ \\
\hline 6 & B3 & 0.00 & 6.8 & $0,001-0,03$ \\
\hline 7 & C1 & 0.00 & 6.9 & $0,001-0,03$ \\
\hline 8 & C2 & 0.00 & 7.0 & $0,001-0,03$ \\
\hline 9 & C3 & 0.00 & 7.0 & $0,001-0,03$ \\
\hline
\end{tabular}

Keterangan:

A.Lokasi berjarak 500 meter dari tempat tromol;

B.Lokasi berjarak 250 meter dari tempat tromol;

C.Lokasi berjarak 25 meter dari tempat tromol

Hasil analisis kandungan merkuri pada ke9 sampel tumbuhan pakis dari ke-3 lokasi semuanya tidak mengandung merkuri (Tabel 1).Pengambilan sampel berdasarkan tumbuhan yang tampak tumbuh subur dan tidak memperhatikan umur tumbuhan. Berdasarkan pengamatan di lokasi, ke-9 tumbuhan paku yang dijadikan sampel berasal dari tumbuhan yang tumbuh subur dan tidak terganggu pertumbuhannya. Menurut Widyati (2011) tumbuhan yang tumbuh subur tanpa terganggu pertumbuhannya, karena tumbuhan tersebut memiliki kemampuan mengakumulasi dan mentranslokasi logam berat termasuk merkuri yang dapat tumbuh di kawasan tersebut, termasuk salah satu tumbuhan hipertoleransi.

Hasil penelitian menunjukkan tumbuhan paku memiliki sifat hipertoleran karena dapat tumbuh subur di kawasan penambangan emas rakyat di Desa Talawaan-Tatelu. Namun tumbuhan pakis belum dapat dikategorikan tumbuhan hiperakumulator logam berat merkuri karena masih membutuhkan data kandungan merkuri di akar dan batang untuk melengkapi syarat menjadi tumbuhan hiperakumulator yaitu mampu mengakumulasi logam dengan konsentrasi tinggi pada jaringan akar, batang, dan daun sehingga bersifat hiperakumulator. Bersifat toleran terhadap kandungan logam yang tinggi sehingga pertumbuhan akar dan pucuk tidak mengalami hambatan. Tanaman yang toleran tidak akan terganggu pertumbuhannya walaupun tumbuh pada tanah dengan toksisitas yang tinggi. Toleransi ini diduga berasal dari kemampuan tanaman untuk menyimpan logam dalam vakuola sel atau mampu mengkelat logam-logam (Chaney., 1997 dalam Widyati, 2011).

Pada penelitian ini tumbuhan paku yang berada lokasi ke-3 tidak memiliki kemampuan mengakumulasi merkuri dalam jumlah yang tinggi sehingga tidak dapat digolongkan sebagai tumbuhan hiperakumulator. Sifat hiperakumulator berarti dapat mengakumulasi unsur logam tertentu dengan konsentrasi tinggi pada tajuknya dan dapat digunakan untuk tujuan fitoekstraksi. Dalam proses fitoekstraksi ini logam berat diserap oleh akar tanaman dan ditranslokasikan ke tajuk untuk diolah kembali atau dibuang pada saat tanaman dipanen (Hidayati, 2005).

Tumbuhan digolongkan hiperakumulator jika mampu mengakumulasi merkuri $(\mathrm{Hg})$ sebesar $10 \mathrm{mg} / \mathrm{kg}$ berat kering.Namun dalam penelitian ini tidak dilakukan uji kemampuan akumulasi merkuri sebesar $10 \mathrm{mg} / \mathrm{kg}$ berat kering. Menurut Juhaeti, dkk (2009) kriteria suatu jenis tumbuhan dapat digolongkan sebagai hiperakumulator adalah: (1)Tahan terhadap unsur logam dalam konsentrasi tinggi pada jaringan akar dan tajuk; (2)Tingkat laju penyerapan unsur dari tanah yang tinggi dibanding tanaman lain; (3)Memiliki kemampuan mentranslokasi dan mengakumulasi unsur logam dari akar ke tajuk dengan laju yang tinggi; (4)Secara ideal memiliki potensi produksi biomasa yang tinggi.

Tumbuhan paku yang tumbuh subur di lokasi pertambangan emas rakyat TalawaanTatelu digolongkan sebagai tumbuhan hipertoleransi terhadap merkuri.Hal ini disebabkan oleh kemampuan tumbuhan tersebut dalam menyerap merkuri. Ada terdapat 2 faktor yang mempengaruhi proses penyerapan logam berat yaitu: (1) Perbedaan genetik dalam serapan, translokasi dan menolak atau menyimpan kontaminan oleh tanaman, dan (2) Faktor lingkungan. Umur tumbuhan juga merupakan salah satu penentu dalam penyerapan merkuri, namun dalam 
penelitian ini tidak diketahui umur setiap tumbuhan pakis yang dianalisis.Banyaknya serapan logam oleh tumbuhan tergantung pada umur tumbuhan, banyaknya logam dalam tanah dan lamanya waktu tumbuhan berada pada tanah tercemar (Ashraf et al, 2010).

Pengambilan sampel tumbuhan paku terbatas pada daun bagian atas yang terlihat masih muda, karena bagian tersebut yang paling banyak dipetik untuk dikonsunsi.Merkuri biasanya masuk ke dalam tubuh manusia lewat pencernaan, baik melalui ikan maupun air.Apabila terjadi akumulasi yang lebih, dapat berakibat pada degenerasi sel-sel saraf di otak kecil yang menguasai kondisi saraf, gangguan pada luas pandang, degenerasi pada sarung selaput saraf dan bagian otak kecil. Unsur ini dapat bercampur dengan enzim di dalam tubuh manusia menyebabkan hilangnya kemampuan enzim untuk bertindak sebagai katalisator untuk fungsi tubuh yang penting (Setiabudi, 2005).

$\mathrm{pH}$ dapat mempengaruhi akumulasi logam berat pada tumbuhan dan berhubungan dengan meningkatnya daya larut logam (Connel, 1995). Tanah yang asam akan menaikan pembebasan logam dalam tanah termasuk logam yang toksik. Derajat keasaman yang tinggi mempengaruhi penyerapan dalam tanah. Naiknya ketersediaan logam dalam tanah dapat meningkatkan kandungan logam dalam tanaman. Jika terjadi penurunan $\mathrm{pH}$ maka logam akan menghilang karena proses pelarutan. Akumulasi logam dalam tanah tidak hanya tergantung pada kandungannya dalam tanah tetapi juga tergantung pada jenis tanaman (Darmono, 1995).Hasil pengukuran pH tanah pada ke-9 lokasi pengampilan sampel tumbuhan paku menunjukkan pada kisaran 6.5 sampai dengan 7.0 (suasana netral).

Pertambangan rakyat yang dilakukan sejak tahun 1998 melibatkan 262 sampai 3289 penambang. Pencemaran yang sedang terjadi di Desa Talawaan-Tatelu adalah pencemaran logam berat merkuri yang bersumber dari kegiatan pertambangan emas. Limbah hasil pengolahan emas secara sengaja dibuang di sekitar daerah pengolahan yang biasanya berada di sekitar daerah aliran sungai sehingga limbah yang mengandung merkuri akan mengkontaminasi sepanjang aliran sungai, lingkungan rumah penduduk setempat, dan tanaman sekelilingnya (Rondonuwu et al., 2012).

Merkuri yang digunakan dalam pengolahan emas di Talawaan-Tatelu yaitu merkuri yang berwarna putih berkilau dan berbentuk cair. Menurut Inswiasri (2008), merkuri metal $(\mathrm{Hg} 0)$ merupakan logam berwama putih dan berkilau. Pengolahan emas di Desa Ilangata menghasilkan limbah yang mengandung merkuri metal $(\mathrm{Hg} 0)$, Merkuri metal $(\mathrm{Hg} 0)$ banyak digunakan pada proses amalgamasi untuk pemurnian emas karena sifatnya yang berwujud cair pada suhu kamar.

Menurut Palar (1994) ada beberapa efek yang ditimbulkan oleh merkuri terhadap tubuh antara lain: (1) Semua senyawa merkuri adalah racun bagi tubuh, apabila berada dalam jumlah yang cukup; (2) Senyawa-senyawa merkuri yang berbeda, menunjukkan karakteristik yang berbeda pula dalam daya racun yang dimilikinya, penyebarannya, akumulasi dan waktu retensinya di dalam tubuh; (3) Biotransformasi tertentu yang terjadi dalam suatu tatanan lingkungan, dan atau dalam tubuh organisme hidup yang telah kemasukan merkuri disebabkan oleh perubahan bentuk atas senyawa-senyawa merkuri, dari satu tipe ke tipe lainnya; (4) Pengaruh utama yang ditimbulkan oleh merkuri di dalam tubuh adalah menghalangi kerja enzim dan merusak selaput dinding (membran) sel. Keadaan itu disebabkan karena kemampuan merkuri dalam membentuk ikatan kuat dengan gugus yang mengandung belerang (sulfur) yang terdapat dalam enzim atau dinding sel; (5) Merkuri dalam tubuh umumnya bersifat permanen.

Hasil analisis tanah menunjukkan bahwa kandungan merkuri pada lokasi berjarak 500 meter dan 250 meter sebesar 0 ppm, sedangkan lokasi ke-3 yang berjarak 25 meter sebesar $0.06 \mathrm{ppm}$ (Tabel 2). Tingginya kandungan merkuri ini pada tanah disebabkan karena sangat terdekat dengan pengolahan emas secara amalgamasi.

Hasil penelitian menunjukkan lokasi C yang berjarak 25 meter dari tromol memiliki kandungan merkuri sebesar 0.06 ppm namun ke-3 sampel tumbuhan paku di lokasi $\mathrm{C}$ tidak mengandung merkuri. Kandungan merkuri pada tanah di lokasi penelitian masih berada dibawah standar baku mutu yang diperbolehkan yaitu diantara $<0.001 \mathrm{~s} / \mathrm{d} 0.3$ ppm. 
Tabel 2. Kandungan Merkuri Pada Tanah

\begin{tabular}{|c|c|c|c|}
\hline No & Sampel & $\begin{array}{c}\text { Kadar } \\
\text { Hg } \\
(\mathrm{ppm})\end{array}$ & $\begin{array}{c}\text { Standar Hg } \\
\text { pada } \\
\text { Tanah(ppm) }\end{array}$ \\
\hline 1 & A & 0.00 & $<0,01-0,3$ \\
\hline 2 & B & 0.00 & $<0,01-0,3$ \\
\hline 3 & C & 0.06 & $<0,01-0,3$ \\
\hline
\end{tabular}

Keterangan:

A.Lokasi berjarak 500 meter dari tempat tromol;

B.Lokasi berjarak 250 meter dari tempat tromol;

C.Lokasi berjarak 25 meter dari tempat tromol

Kandungan logam dalam tanah sangat berpengaruh terhadap kandungan logam pada tanaman yang tumbuh diatasnya, kecuali terjadi interaksi diantara logam itu sehingga terjadi hambatan penyerapan logam tersebut oleh tanaman.Akumulasi logam dalam tanaman tidak hanya tergantung pada kandungan logam dalam tanah, tetapi juga tergantung pada unsur kimia tanah, jenis logam, pH tanah, dan spesies tanaman (Darmono, 1995).

Standar baku mutu kelimpahan logam berat merkuri pada tanah berkisar $<10-300$ ppm. Berdasarkan hasil penelitian pada bekas penambangan emas mandor umur 4-5 tahun, 6-10 tahun dan 11-15 tahun, kadar masingmasing merkuri adalah $0,020 \mathrm{ppm}, 0,050 \mathrm{ppm}$ dan 0,042 ppm dengan rerata 0,037 ppm.Sebaran merkuri pada jarak $100 \mathrm{~m}$ lebih kecil dibandingan dengan sebaran merkuri pada jarak $500 \mathrm{~m}$ dan $300 \mathrm{~m}$, hal ini disebabkan karena jarak $100 \mathrm{~m}$ lebih dekat dengan sungai dibandingkan jarak $500 \mathrm{~m}$ dan $300 \mathrm{~m}$ sehingga merkuri yang ada terbawa oleh arus aliran sungai dan kondisi curah hujan yang tinggi juga membantu disperse unsur merkuri. Sebaran merkuri mengalami penurunan pada kedalaman tailing 39-41 cm dikarenakan sebelum masuk ke dalam tanah, merkuri terlebih dahulu mengalami pencucian oleh aliran air. Kadar merkuri pada vegetasi (>61 \%) memiliki nilai yang rendah dibandikan dengan penutupan vegetasi ( 0 $30 \%$ ) dan (31-60\%) dikarenakan merkuri yang berada di dalam tanah akan semakin berkurang karena terserap oleh vegetasi melalui akar (Stwertka, 1998)

Penambangan emas yang berada di Desa Talawaan-Tatelu telah beroperasi sejak tahun 1998 yang lalu.Kandungan merkuri pada lahan penambangan emas yang berjarak 25 meter sebesar 0.06 ppm.Dari beberapa kasus akibat merkuri, dilaporkan telah melebihi ambang batas yang ditetapkan, antara lain oleh Food and Dung Administrasion (FDA) menetapkan ambang batas kandungan merkuri maksimum 0,0005 ppm untuk air dan 0,5 ppm untuk makanan, sedangkan Word Health Organisasion (WHO) menetapkan batasan maksimum yang lebih rendah yaitu 0,0001 ppm untuk air. Jepang, Swiss, Swedia menetapkan ambang batas $1 \mathrm{ppm}$ produk laut yang boleh dikonsumsi, sedangkan pemerintah Jerman dan AS menetapkan 0,5 ppm (mg/kg).

Pemerintah Indonesia memberi batas melalui Baku Mutu Ambient dan Limbah yang ditetapkan oleh pemerintah Republik Indonesia dengan KEK-2/MENKLH/1/1988. Baku mutu air untuk golongan A dan B kandungan merkuri maksimum yang dianjurkan 0,0005 ppm dan maksimum yang diperbolehkan sebesar 0,0001 ppm. Pada air golongan $\mathrm{C}$ kadar maksimum yang diperbolehkan sebesar 0,002 ppm, sedangkan golongan D sebesar 0,0005 ppm. Untuk baku mutu air limbah kandungan merkuri yang diijinkan untuk air golongan I sebesar 0,001 ppm, golongan II sebesar 0,002 ppm, golongan III sebesar 0,005 ppm sedangkan golongan IV sebesar $0,001 \mathrm{ppm}$. Penelitian awal tahun 2002 mengungkapkan konsentrasi merkuri $(\mathrm{Hg})$ pada tailing sebesar 55,161 ppm, sedimen 2,599ppm, tanah 2,188 ppm, rumput 1,468 ppm, ikan 0,850 ppm dan kerang 2,104 ppm, seluruhnya telah berada di atas ambang batas (Tulalessy, 2005). Namun data hasil penelitian kandungan merkuri pada tumbuhan paku tidak mendukung data sebelumnya karna sampel daun muda tumbuhan paku tidak lagi mengandung merkuri, hal tersebut menunjukkan terjadinya penurunan pencemaran merkuri di lokasi penambangan emas di Talawaan-Tatelu.

\section{KESIMPULAN}

Hasil penelitian menunjukkan bahwa tidak terdapat kandungan merkuri pada tumbuhan paku sayur (Diplazium accedens Blume) yang berada di lokasi berjarak 500 meter, 250 meter, maupun 25 meter. Sedangkan hasil analisis tanah menunjukkan bahwa kandungan merkuri pada lokasi berjarak 500 meter dan 250 meter sebesar 0 
ppm, sedangkan lokasi ke-3 yang berjarak 25 meter sebesar 0.06 ppm.

Hasil penelitian menunjukkan tumbuhan paku memiliki sifat hipertoleran karena dapat tumbuh subur di kawasan penambangan emas rakyat di Desa Talawaan-Tatelu. Namun tumbuhan paku belum dapat dikategorikan tumbuhan hiperakumulator logam berat merkuri karena masih membutuhkan data tambahan tentang kandungan merkuri di akar dan batang untuk memenuhi kriteria tumbuhan hiperakumulator yaitu mampu mengakumulasi logam dengan konsentrasi tinggi pada jaringan akar dan tajuknya, sehingga bersifat hiperakumulator.

Data penelitian kandungan merkuri pada tumbuhan paku tidak lagi mengandung merkuri, hal tersebut menunjukkan terjadinya penurunan pencemaran merkuri di lokasi penambangan emas di Talawaan-Tatelu.

\section{DAFTAR PUSTAKA}

Anonim.2009. UU No. 32 tahun 2009 tentang Perlindungan dan Pengelolaan Lingkungan Hidup. Jakarta

Alfian, Z. 2006. Merkuri : Antara Manfaat dan Efek Penggunaanya Bagi Kesehatan Manusia dan Lingkungan.[Skripsi]. Universitas Sumatera Utara. Medan.

Ashraf, M., Otzurk, M., S.A Ahmad. 2010. Plant Adaptation and Phytoremediation. Springer Dordrecht Heidelberg. New York.

Connell, D.W. 1995. Bioakumulasi Senyawa Xenobiotik. UI-Press. Jakarta.

Chaney, R.L . 1995. Potential use of metal hyperaccumulators [Skripsi]. Mining Environ Manage.

Chaney, R.L. 1997. Phytoremediation of soil metals. Curr Opini Biotechnol 8:279-284.

Campbell, N.A., Reece J.B., Mitchell, L.G. 2000. Bilogi Jilid IIEdisi kelima. Penerbit Erlangga. Jakarta.

Darmono. 1995. Logam Dalam Sistem Biologi Makhluk Hidup. UI-Press. Jakarta.

Darmono. 2006. Lingkungan Hidup dan Pencemaran: Hubungannya dengan Toksikologi Senyawa Logam. UI-Press. Jakarta.
Hidayati, N. 2005.Fitoremediasi dan Potensi Tumbuhan Hiperakumulator.Hayati. 12 (1):35-40.

Hardiani, H. 2008. Pemulihan Lahan Terkontaminasi Limbah B3 dari Proses Deinking Industri Kertas Secara Fitoremediasi.Riset Industri. (2):64-75.

Hardiani, H. 2009. Potensi Tanaman Dalam Mengakumulasi Logam $\mathrm{Cu}$ Pada Media Tanah Terkontaminasi Limbah Padat Industri Kertas. BS. 44(1): 27-40.

Inswiasri. 2008. Paradigma Kejadian Penyakit Pajanan Merkuri (Hg). Ekologi Kesehatan. 7 (2): 775-785.

Juhaeti, T., Fauzia, Syarif.2009. Potensi Centrocema pubescence, Calopogonium mucunoides, dan Micania cordata dalam Membersihkan Logam Kontaminan pada Limbah Penambangan Emas. Biodiversitas. 7 (1): 4-6.

Kinho, J. 2011. Keanekaragaman Jenis Tumbuhan Paku di Taman Nasional Aketajawe-Lolobata. Balai Penelitian Kehutanan Manado.[Skripsi].Manado.

Lakitan, B. 2001.Dasar-dasar Fisiologi Tumbuhan. Raja Grafindo. Persada. Jakarta.

Leksono, A.S.2007.Ekologi Pendekatan Deskriptif dan Kuantitatif. [Skripsi].Bayumedia. Malang.

Manik, K.E.S. 2003. Pengelolaan Lingkungan.Djambatan. Jakarta.

Meagher, R. B. 2000. Phytoremediation of Toxic Elemental and Organic Pollutants. Department of Genetics. [Skripsi]. University of Georgia,s. Athens.

Palar, H. 1994.Pencemaran dan Toksikologi Logam Berat. Rineke Cipta. Jakarta.

Rompas, R.M., M. Karouw, N.J. Kawung.1994. Determinasi Pencemaran Logam Berat di Lingkugan Perairan Sulawesi Utara. [Skripsi].UNSRAT. Manado.

Rondonuwu, S.B., D.W. Santosa, Suprihaatin. 2012. Uji Aktivitas Bakteri Merkuri Asal PESK Talawaan-Tatelu, Kabupaten Minahasa Utara, Provinsi Sulawesi Utara. Forum Pascasarjana IPB. Bogor. 35(3):167-177. 
Sastrapradja, S., J.J. Afriastini, D. Darnaedi, E.A Widjaja.2002. Jenis Paku Indonesia.Lembaga Biologi Nasional. [Skripsi].LIPI. Bogor. 129p.

Setiabudi, T.B., 2005. Penyebaran Merkuri Akibat Usaha Pertambangan Emas di Daerah Sangon, Kabupaten Kulon Progo, D.I. Yogyakarta. Kolokium Hasil Lapangan. DIM. 61 (1-17).

Tulalessy A.H. 2005. Studi Pencemaran Merkuri pada Kawasan Penambangan Emas Rakyat Tatelu Sulawesi Utara [Disertasi]. Institut Pertanian Bogor. Bogor

Wardhana, W.A. 2004.Dampak Pencemaran Lingkungan. Andi. Yogyakarta

Widhiyatna, D.2005. Pendataan Penyebaran Merkuri Akibat Pertambangan Emas di Daerah Tasikmalaya Propinsi Jawa Barat. [Skripsi].Jawa Barat.

Widyati, 2011. Potensi Tumbuhan Bawah Sebagai Akumulator Logam Berat Untuk Membantu Rehabilitasi Lahan Bekas Tambang. Mitra Hutan Tanaman. 6 (2): $46-56$. 